\title{
Transient Spaces: Building Community in Crisis Contexts
}

\author{
LOUKIA TSAFOULIA \\ City College of New York
}

Transiency no longer appears as a condition of exception, but rather as the predominant mode of existence in many parts of the world. The increased tension across and beyond national borders and territorial divisions has drawn the attention of designers across the globe and densified our reflections on questions of identity, equality, politics and economic exchange, expanding the reach of design from the realm of physical forms, into modes of interaction in social spaces. Planners and architectsare beingchallenged tocreate infrastructural systems and new spatial structures ofunparalleled resilience and elasticity. The paper presents part our research on the refugee crisis in the context of Greece, intertwined with the process and the experience gained as part of an advanced design studio Loukia Tsafoulia developed and taught during spring 2017 at the City College of New York. After its conclusion, the studio triggered an international call for contributions and it is currently under development for a book publication titled Transient Spaces, that explores conditions of impermanence and aims to stimulate conversations on issues of belonging and displacement.

\section{INTRODUCTION}

Refugee Flows and the European Context.

The nation of the Displaced is growing rapidly. With 65.6 million of displaced people by the end of 2016, a number increasing by the end of 2017, if it were a country it would be the 21st largest in the world. ${ }^{1}$

- Michael Doyle, Professor at Columbia University, Director of the Columbia Global Policy Initiative

Based on data from the UN Refugee Agency, ${ }^{2}$ more than 65 million people are displaced by conflict and war worldwide and the past 6 years the number has escalated because of the war in Syria. The Mediterranean basin specifically is crossed every day by large and uncontrolled flows of people of every age. As Europe dithers and the rest of the world keeps its distance, a few countries amongst which, Lebanon, Jordan, Turkey and Greece carry the burden of hosting some four million refugees.

Europe's architecture faults are coming to the fore. Moral values collide with practical concerns, while public opinion fluctuates between compassion and fierce hostility. Refugees, especially in transit, have been subjected to extreme racism. Simultanesously, the rise of nationalist, xenophobic parties across Europe that are using 'the refugee problem' as their political tool results in the mobilization of a far right populism

\author{
SEVERINO ALFONSO \\ Universidad Politécnica de Madrid
}

Zooming in the case of Greece, it is important to note its key geopolitical location situated along the Mediterranean Sea. During the past two years, 1.3 million people fleeing conflict and persecution have traveled through Greece's islands and the mainland on their way to Europe. There were 200 reported deaths of migrants in the Aegean Pelagus recorded in 2016. With the closure of the Balkan borders and the implementation of the EU-Turkey agreement in March 2016, people have been forced to wait in temporary camps.

\section{DESIGN STUDIO OBJECTIVES: THE CASE OF GREECE Questions, research and the case study sites of the design studio.}

Having these in mind, the design studio developed strategies for disaster response that show economic and social sustainability through community integration strategies in the context of Greece. It concerned the design of community driven, systems approach and investigated alternative ways for addressing everyday, context-based issues that are less dependent on the global relief industry. In an effort to establish bridges between academic research and the various professionals involved in the humanitarian support mechanisms, the design studio connected with members from the Danish Refugee Council, the Greek Ministry of Immigration Policy and the UN Refugee Agency. Even though the studio engaged in active discussions with professionals involved in the humanitarian mechanisms one of the basic questions asked was, how can design disrupt power structures in relief response?

Currently, camp design is guided by a series of pamphlets published by the United Nations High Commissioner for Refugees. Although a certain amount of objectivity is expected through the administration of both non-governmental organizations and the UN Refugee Agency, the reality is that private actors and donors direct these guidelines. Design of new camps often falls into the politics and current demand of the situation which is quick and cheap to ensure the placement of the displaced populations. Together with the concern on relief power structures, a couple more of the questions the studio addressed were: Could our methods adopt to the ever-increasing need for sheltering amidst ongoing crisis? How can architects optimize the capacity of people in acute need of protection while ensuring a high degree of livability and a sense of community and equality? Issues of temporality and space adaptation were investigated. The tactics of appropriation, severance, fragmentation and cultural identification of urban space were examined as, simultaneously, forces and reactions in the physical space in order to construct an ideological position. 

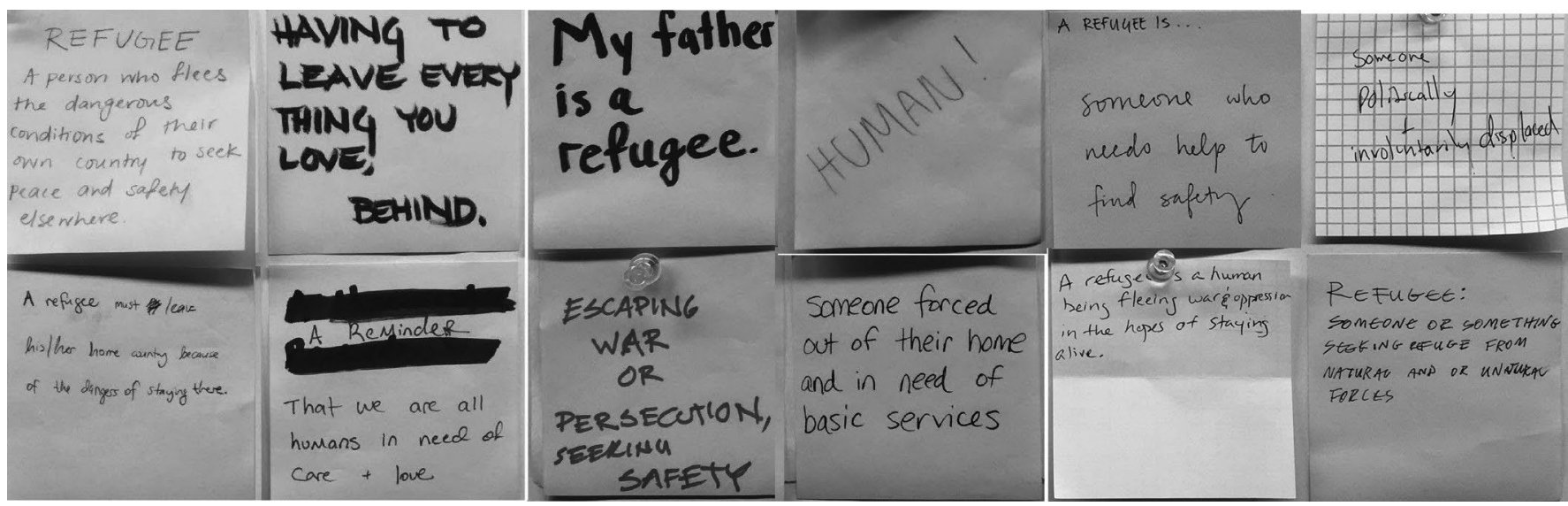

Figure 1: Answers from the poll organized by the 'Transient Spaces' design studio students on the question: what is a refugee? The poll included approximately 50 participants of various ages and backgrounds and was conducted during Spring 2017.

In terms of the studio's process and research strategies, scholarly work on themes such as Belonging, Inhabitants Participation in Design, Self-Organization, Shelter, Publics set the base for the design investigations. Overall, the studio mapped information for the following categories: the people in need, current policies, urban precedents, camp sites, the sheltering structures, the programs and the stakeholders involved. These became the backbone for the interventions proposed. Students identified new languages to bridge across the various actors, organizations and operational forces on the intervention sites, by employing new data sets, mapping flexible infrastructures and addressing a persistent lack of communication that their research revealed.

\section{RESEARCH: DEFINITIONS}

What is a refugee?

A refugee is someone who has been forced to flee his or her country because of persecution, war, or violence. A refugee has a well-founded fear of persecution for reasons of race, religion, nationality, political opinion or membership in a particular social group. Most likely, they cannot return home or are afraid to do so. War and ethnic, tribal and religious violence are leading causes of refugees fleeing their countries. ${ }^{3}$

\section{-Definition provided by the UN Refugee Agency}

The research started by gathering definitions of the word refugee from the formally 'agreed' constructions to more personal understandings of the word (figure 1).

The idea is to explore how the foundation of particular subjectivities - the refugee, the immigrant, the displaced, the detained - is instrumental to the formulation and application of rights and restrictions to individual and collective bodies. These include access to property, labor, mobility which in turn are important values to every city's design and development models.

\section{RESEARCH: ASYLUM POLICIES AND SITE CATEGORIES}

The asylum policies for incoming immigrants in Greece are complex (figure 2). Following the EU-Turkey Statement of 2016, all migrants that apply for asylum, await for Asylum Service's decision while staying within the premises of Reception and Identification Centers, except for those who belong to vulnerable groups and the unaccompanied minors who can be transferred to the mainland right after their asylum application is registered. Based on information provided by Efi Latifi from the Technical Support Department of R.I.S (Reception \& Identification Service), a 2016 law foresees different site categories:

1st site category are the 'Reception \& Identification Centers', also known as 'Hotspots', situated near the Greece - Turkey borderline for all the newcomers that are basically mixed migrant population. These centers serve as the authority for the screening procedure of all third-country nationals and as accommodation centers at the same time.

Actors present at the hotspots are the Reception and Identification Service, the European Asylum Support Office (EASO), the Greek Asylum Service, the Hellenic Police, the FRONTEX (European Border and Coast Guard Agency), the Europol, the International Organization for Migration, the UN Refugee Agency, various NGOs, the Greek Ministries of Health and of Education among others.

Hotspots are meant to be hyper-temporary with maximum duration of up to 25 days, average duration 2 to 3 days, but this is not the case. A bottleneck effect has occurred, where many of the hotspots cannot accommodate the intense flows of people which at times reach more than 1,000 arrivals per day.

When the maximum capacity is exceeded, every kind of temporary structures are used (Rub Halls, Life shelters and various types of Tents) for the immediate accommodation 

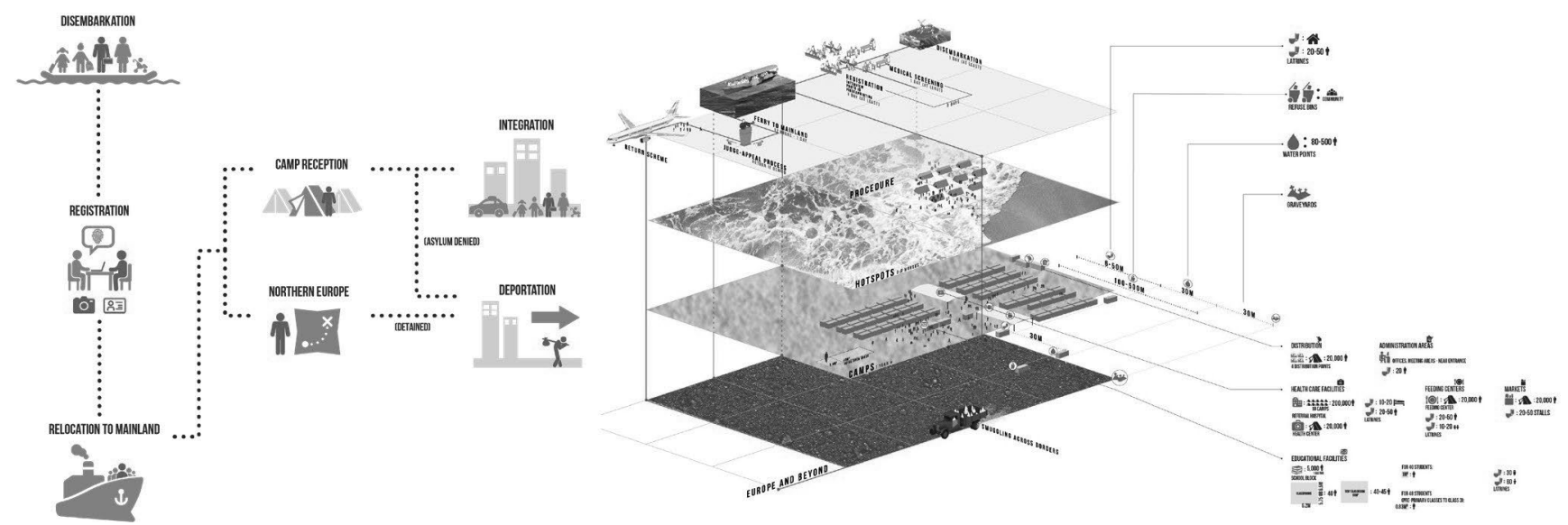

Figure 2: Illustration by the studio students Samantha Ong \& Juan Vallejo showing the arrival processes, asylum policies and site categories, Spring 2017. The illustration is created based on the standards from the Sphere Project, ed. 2001 and the Camp Management Toolkit.

of the incoming migrants. These spaces can hardly be characterized as dignified since the duration of use does not correspond with the spatial qualities.

Some of the issues reported:

- Lack of privacy.

- Lack of shaded areas.

- Architectures of enclosure with razor wire fences marking the site boundaries.

- Prefab sleeping units or tents arranged in military grids.

- Tensions between different populations and religious conflicts. Aggressive behaviors have occurred between Syrian and Afghan people for example.

2nd site category are the 'Temporary Reception Centers'. These are camps in the mainland currently hosting population consisting mainly of asylum seekers. Even though the nature of these settlements is intended to be temporary, in their majority they turn into permanent communities. Having this in mind, there is a need for planning systems that respond to the gradient level of temporarity and address longerterm perspectives.

A 2011 law foresees an extra site category under the responsibility of the Hellenic Police. The Pre-removal (Detention) Centers for all 'Persons of Concern' in forced return or deportation procedure.

Around 20.000 refugees also live in city apartments subsidized by European programs (free for refugees). Important to mention are 'out of law' initiatives that flourish in urban neighborhoods. There are clusters of squatted or unused buildings run by volunteers together with hosted 'Persons of Concern'. In many cases, the displaced population is also hospitated by citizens. Interestingly, Greece is amid a fragile economic condition the past 6 years but as a general feeling there have not been crucial social tensions through these mixtures.
In conclusion, migrants, refugees, and asylum-seekers are accommodated in different reception centers across the country including military barracks, camping sites, private accommodation (apartments), self-organized informal settlements, and abandoned buildings.

\section{HUMANITARIAN GOVERNANCE: THE CASE OF GREECE Ambitions beyond humanitarianism?}

It is important to examine who are the stakeholders involved in the humanitarian processes since many conflicts between the various actors, agents, professionals involved in the humanitarian support mechanisms have been reported. Operations are often both managed and designed from a distance, creating additional environmental, social, and health issues within camps.

Based on the article "Where did the money go?" by Daniel Howden and Apostolis Fotiadis, published on March of 2017:4

[T] oday even though the management of the camps appears to happen through sections of Greek governance the reality is that the Greek government did not receive significant amounts of funds. The biggest pots of money are controlled by the European Commission (EC), the EU's executive body, which oversees the Asylum Migration Integration Fund and the Internal Security Fund which collectively dedicated $\$ 541$ million to fund Greece's costs related to border control, asylum and refugee protection. Much of the funding on offer was directed via international aid agencies.

When human rights are enacted by humanitarian missions become the rights of those who have no rights, the rights of bare human beings subjected to inhuman repression and inhuman conditions of existence. When rights that appear to be useless in their place are sent 

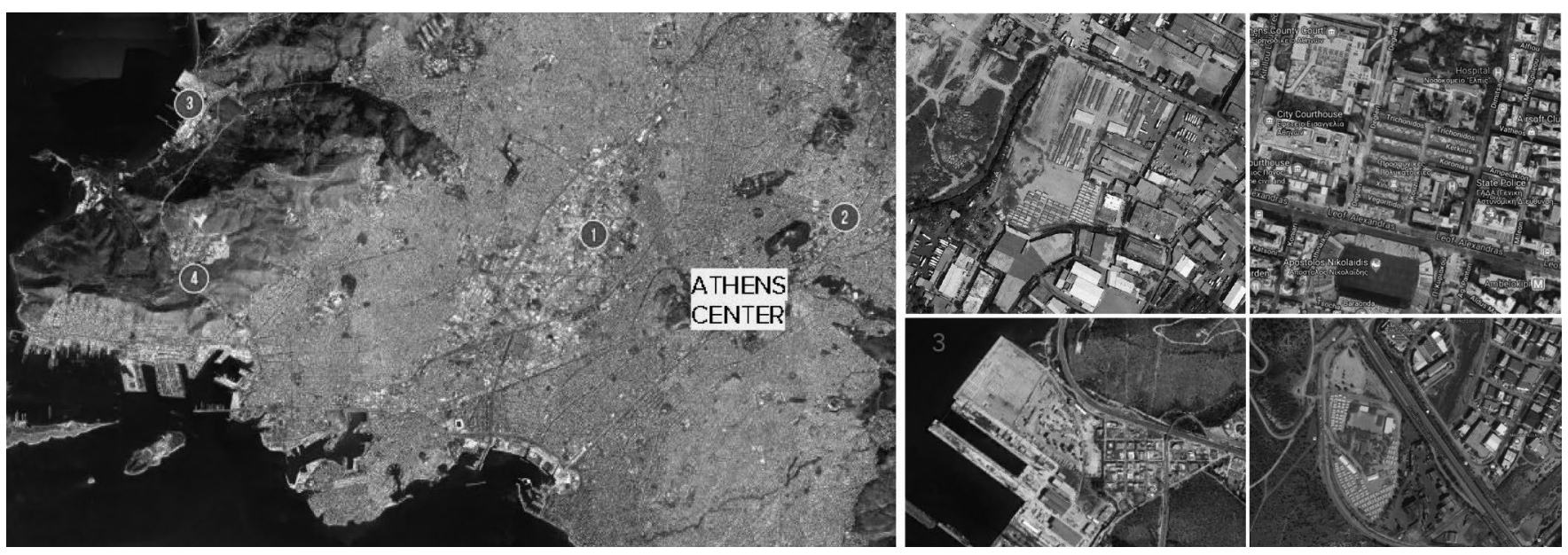

Figure 3: Selected sites in Athens, Greece for the studio design interventions.

abroad, along with medicine and clothes to people deprived of medicine clothes, and rights, [...] and they become humanitarian rights.

-Jacques Rancière in "Who Is the Subject of the Rights of Man?" 5

June 2015, the widely known image of the drowned Syrian toddler Alan Kurdi becomes viral in all social media. In no time, more funds become available by public donations to International Non-Governmental Organizations (INGOs). There was an ethical imperative for the INGOs to show that they were responding to events in the eastern Mediterranean and to show a presence in Greece.

Based on the same article, the problems and the challenges this sudden influx of funds brought, are that for the established groups already working in Greece, there is a disruption of balances. International staff earn three times more than their local counterparts; Local staff are sidelined. The wellfinanced foreign organizations are therefore now seen more as colonialists than as humanitarians. In a more symbolic note, the tide of money transformed refugees into 'commodities' and encouraged short-term responses.

\section{HISTORICAL CONSIDERATIONS}

Humanitarian mechanisms and their political and material implications in the making of physical space.

The question on power structures and control in relief response is a vital one and this short parallel story attempts to develop an argument about humanitarian governance through providing a brief historical view of the Minor Asia refugee crisis during the 1920s in Greece and juxtaposing the relief practices then to today's humanitarian mechanisms. Between September 1922 and January 1923, the mainland of Greece received 1,2 million refugees. It is interesting to see this number next to the 1,3 million refugees who entered Greece between 2015 and 2017.
Similarly to today, during the 1920s the management of the refugee crisis was first relinquished to philanthropic organizations, the military, and the nascent international organizations. Soon, the Refugee Settlement Committee, a humanitarian agency initiated and supervised by the League of Nations (now United Nations) was established.

Platon and Theodossis Issaias on their essay "Displaced, In Place and In Transit, Refugee Population in Greece and the formation of planning protocols and domestic machines" 6 argue that the history of modern town planning in Greece begins as a response to the unprecedented humanitarian crisis provoked in cities, towns, and rural areas with the arrival of the refugee population. Based on this text, "the formation of humanitarian government -the planetary system of League of Nations agencies, NGOs, philanthropic institutions, and financial resources- transformed cities and territories materially and politically. Militarized, highly control camps, refugee settlements, towns and neighborhoods were designed and distributed all over Greece. The planning of settlements, the building of domestic units, the re-distribution of agricultural land, necessitated the organization of complex bureaucratic procedures, administered by the Refugee Settlement Committee." As today, also then drawing from practices of the colonial administrations and by invoking the techno-scientific knowledge of management, the Committee implemented policies that sought to reduce the time of relief aid.

\section{CASE STUDY SITES}

Individuals legal status, camps program and shelter structures.

Closing the parenthesis and back to the studio, the design investigations used as case studies four distinct sites in Athens, Greece (figure 3). The selection was based on various degrees of temporality ranging from spontaneous or planned refugee camps to outside of camp contexts such as dense urban settings. On the outskirts of Athens, 'Schisto' a former military camp, and 'Skaramagkas' a former shipyard facility, are newly 
developed camps in the size of small towns hosting people for an indeterminate amount of time. In the center of Athens, the studio engaged with the 'Eleonas' Camp, a former industrial neighborhood and the 'Prosfygika Alexandras' complex, built to host the 1922 Asia Minor disaster refugees and currently partially abandoned and appropriated by squats. ${ }^{7}$

The legal status of the people in these sites varies; they are refugees, asylum seekers, undocumented migrants and economic migrants. Each category carries with it implications for their legality and rights to claim access to space. In the city center these people are often mixed with a small percentage of homeless population. Having these in mind, the proposed design interventions embraced approaches which could provide overlapping benefits to people regardless of their legal status. For example, undocumented migrant populations could benefit from sharing the resources afforded to refugees arguing for parity and inclusiveness beyond the constructed titles that leave in a law vacuum a large number of people. ${ }^{8}$

In the current camps the program is broken down into categories dictated by the UN Refugee Agency. Basic programs include administration, domesticity, culinary, hygiene, educational and communal spaces. In terms of shelter structures, mostly prefabricated units resembling containers of typical size are used for accommodating one big family or two smaller families.

Acording to Efi Latifi from the R.I.S and Thodoris Marinis from the DRC-Greece, all camps provide basic domestic equipment. There is a distribution point for the Non Food Items (NFIs), a storage and logistics. However, these provisions do not cover the infrastructure limitations (electrical capacity, heating and cooling systems), while other provisions like the catered food has not prevented the users to seek their own cooking habits. These individual attempts for a more regular lifestyle sometimes produces uncontrolled threats of fire, burning indoors, toxic environmental conditions etc.

\section{DESIGN PROPOSALS}

We will provide a quick overview on two of the case study sites and their design proposals. First, the Schisto camp proposal not only reflects the societal need to accommodate more transient populations, but also tackles a question of building re-use with entirely different programs, from a military camp to a reception facility, and the question of whether a camp can possibly transition to an integrated community.

The use of the former military camp is due to its flexibility and availability to respond right away to the immediate needs of Refugees. The current camp master plan is therefore more of an economic decision done forcing a more temporary, bland set up. In an interview during Spring 2017 Thodoris Marinis from the DRC-Greece, claimed that "since 2016 when the beginning of the creation of this refugee camp lies, it has become clear that it is shifting from a sudden event of emergency response to a management of a variable refugee movement of longer time span. As one of the 'prototype' reception facilities, within two years this camp transitioned from tents of prefab structures with embedded kitchenette and of the required communal programs."

Interesting to note is that leftover building materials from the housing prefab installation and the network infrastructure works of winter 2016 were reused by the camp residents. The timber posts, the plastic sheets, tarpaulins were applied in all kinds of DIY ways expressing the users on each front façade. The ingenious ways of re-purposing metal frame beds into storefronts, prayer spaces, front porches and gardens provide a sense of familiarity and community (figure 4). Similarly, in the nearby camp of Skaramagkas along the beautiful waterfront refugees have created structures out of waste material and started their own business, already to be found on Google maps and with excellent ratings; Some of them have made a name of the best kebab in the area.

In that spirit, the studio's research revealed that by enhancing the existing market in the nearby streets of Schisto, and further integrating a marketplace as the driving program, the camp could potentially attract vendors from the neighboring communities of Attica. Following the narrative of the weekly bazaar as the source of income and way of life, the relationship between the vendors and refugees could become linked and mutually beneficial. Once a meeting point is set, there is much space to fill in with activities not only directly commercialized. Musicians and artisans among the refugees already seek for space to practice. Live art performances and lessons exchange with the locals are the next step.

Overall, the team for the Schisto intervention focused on the design of a strategic phasing plan that operates in the policy, social and the material levels to allow for gradual economic and development autonomy and community strengthening through self-organization while promoting integration to the nearby cities. Starting with training opportunities, and community building the idea is to empower the migrants by providing resources and restoring their sense of dignity, allowing them to use their own set of skills or cultivate new ones rather than solely relying on outside aid. The hypothesis is that over time and looking past the 'refugee crisis,' the camp may transition into an established market community for anyone to stay and sell (figure 4).

Second case study is the scenario of revitalizing the 1930s former refugee housing on Alexandras avenue in the center of Athens (figure 5). The main idea behind integration is the creation of spaces that could respond to a more long-term living, which was not the goal in the early stages of camp creation. In response to this concern, the proposal promotes strategies to reduce the occupancy of the camps and create infrastructures to update existing urban buildings. 
WEAVING COMMUNITIES

TRANSITIONING AN EXISTING REFUGEE CAMP INTO AN INTEGRATED COMMUNITY

STUDENTS TEAM:

Juan Vallejo, Samantha Ong, Emir Abdul-Emir, Daniella Vega-Ortiz

\section{TRANSITIONING THE CAMP IN PHASES}
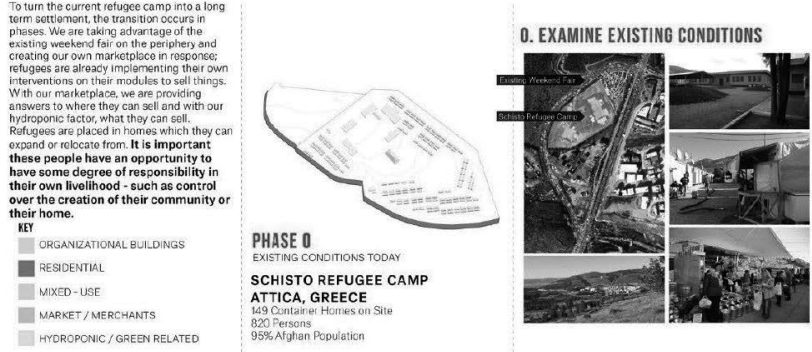

|

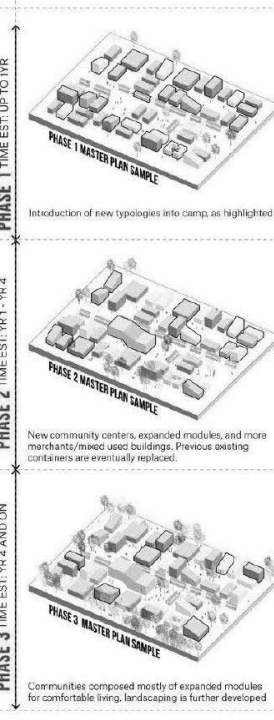

PHASES OF THE CAMP
1. COMMUNITY BUILDING

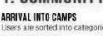

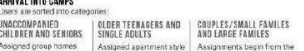

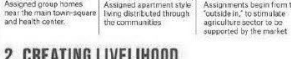

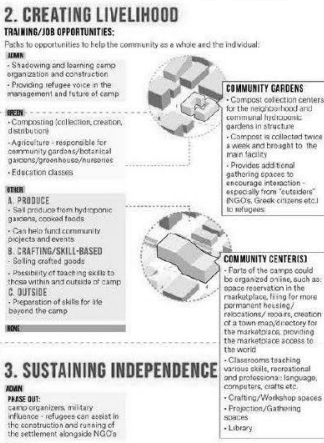

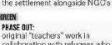

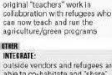

PHASES OF THE USER
Proposal won the RTF 2017

First Award Urban Design Category

\section{THE MASTERPLAN AND ITS PARTS}
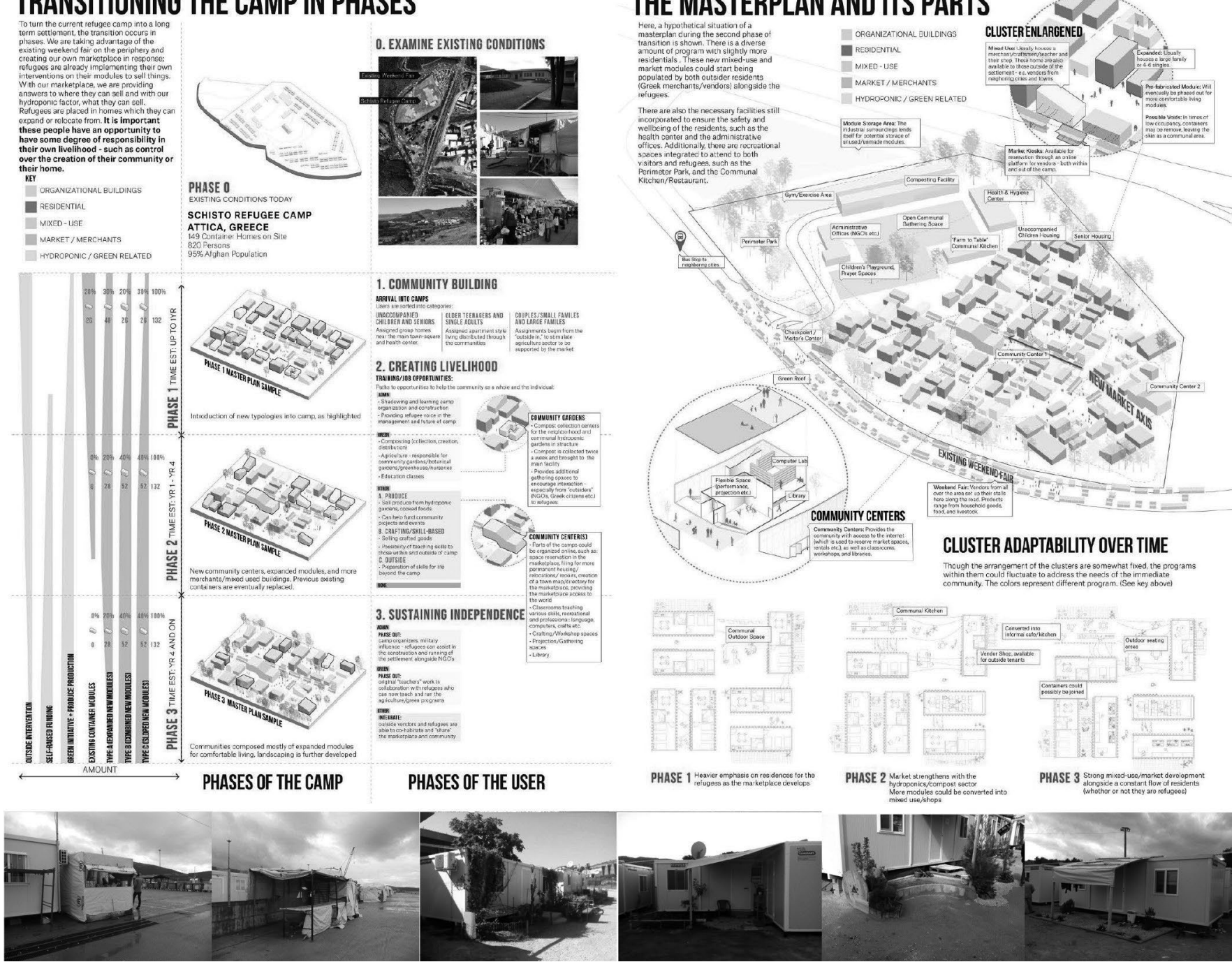

Figure 4: Top: Panel with proposal intervention for the Schisto Camp by studio students. Bottom: Existing camp conditions showing intuitive design and bottom up initiatives. Images by Loukia Tsafoulia \& Thodoris Marinis, 2017.

To add to the discussion of preservation and re-use of such spaces and based on data provided by Thodoris Marinis from the DRC-Greece, the cost to build a camp with prefabricated structures for 1000 people is approximately 5 million euro and to sustain them is certainly more than 500,000 euro yearly. So, to re-purpose the Prosfygika in Alexandras is a financially sound scenario.

Through a phasing strategy, the proposal Re-Action aims to develop a spatial and hybrid programmatic system that adapts to the influx of refugees while integrating them with the economy and locals of Greece. The intervention proposes a series of new typologies that bring communal programs within the existing shell; spaces including computer labs, workshops, projection rooms, reading rooms, shared cooking and dining areas that have the ability to grow and shrink while creating opportunities for the city and the displaced populations to integrate.

The students' work won first prize in the Urban Design category of the international competition Rethinking The Future Sustainability Awards $2017^{10}$ and was also awarded first prize in the Cities of Tomorrow Competition sponsored by Project Earth 2. ${ }^{11}$ 
RE-ACTION

A "SOCIALLY-REFLEXIVE" APPROACH

STUDENTS TEAM:

Francesca Messina, Vionna Wai, Roberto Zhang, Emanuel Gjini

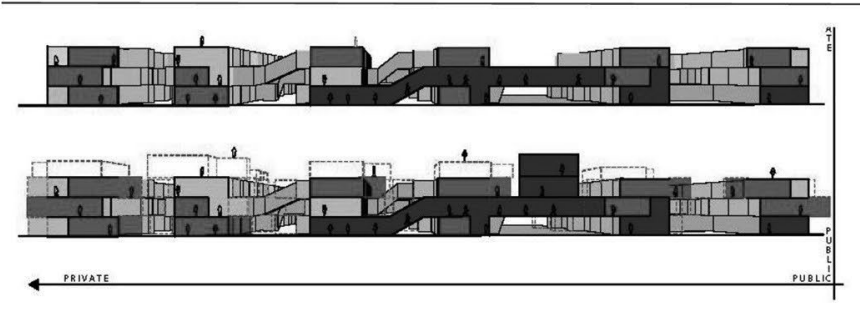

PHASING + LINING MOBILIY
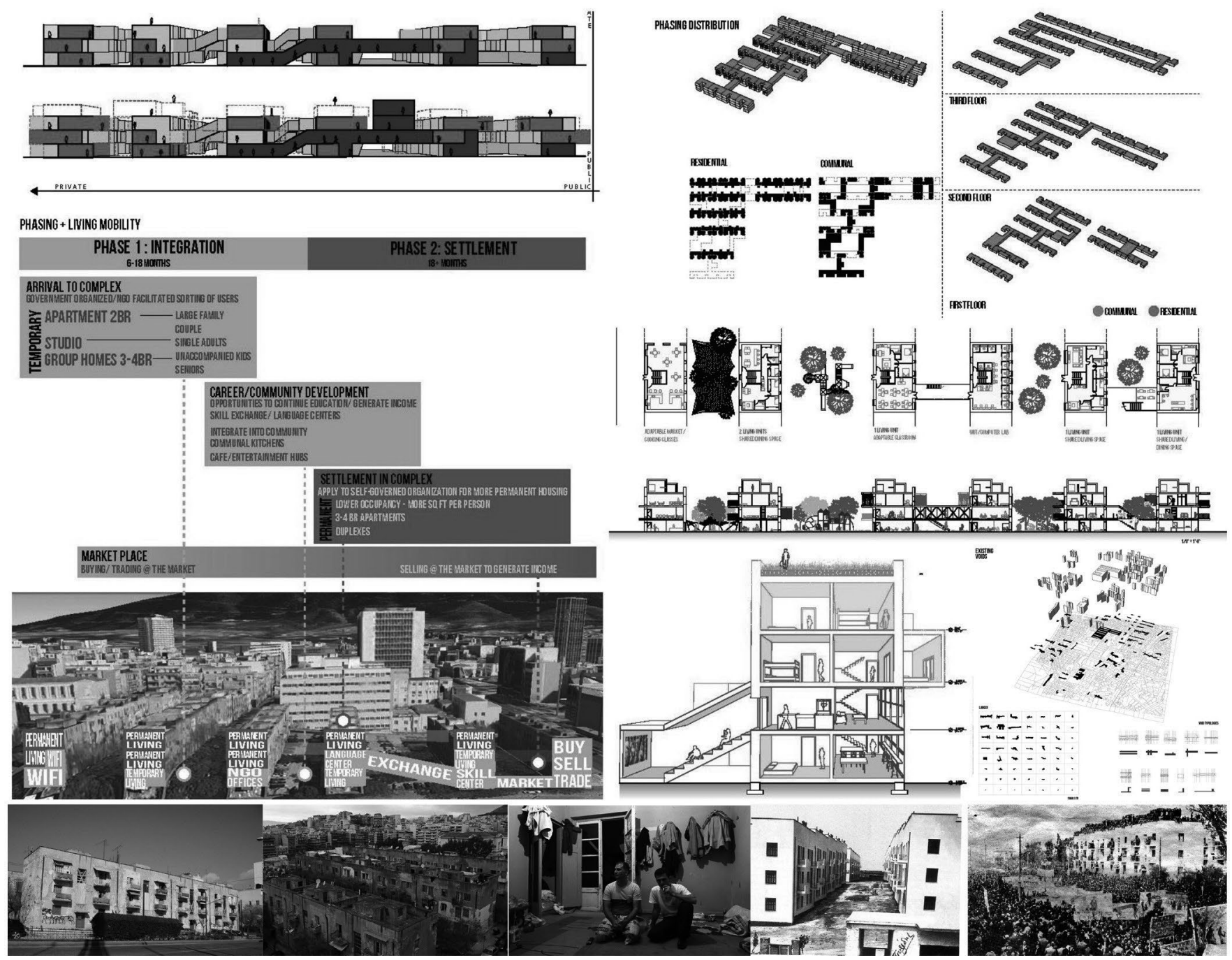

Figure 5: Top: Panel with proposal intervention for the rehabilitation of the Prosfygika Alexandras by studio students. Bottom: Images from the personal

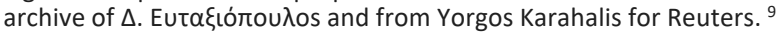

\section{CONCLUSIONS}

By way of conclusion, as forces of change occur we still appear largely disengaged from means of activism which could allow our expertise to interact with more potency, claim pertinence and contribute to the way in which society and the physical environment changes.

At its sharpest my hypothesis is that beneath the country specifics of diverse global crises lie emergent systemic trends shaped by a few very basic dynamics. For that reason, empirical research and conceptual recoding must happen together

-Saskia Sassen in "Expulsions: Brutality and complexity in the global economy."12
We think it is important to intertwine the 'refugee question' and the emergence of humanitarian governance with the spatial, territorial and architectural design practices. Today, the deployment of mechanisms of international humanitarian aid - mainly detention and processing centres, or so-called hospitality centers, eventually militarized camps - coexist with activist interventions including squatting of abandoned properties and open facilities.

As a response then to the beginning investigations of the design studio on camp-based approaches we now consider an out-of-camp and not-camp-related outreach, better for future integration. To that end, we argue that we ask too much from a camp. To become a social hub, the use of existing building 
stock such as empty flats, hotels, houses in Athens and along the refugee routes is much more appropriate. The settlement, the 'temporary shelter', the camp, organize a condition of permanent temporary-ness and a constant suspension of rights. A network of support outside of the international humanitarian infrastructure is emerging. Activist groups, volunteers, anarchists, solidarity networks, have established a landscape of care and an ecology of coexistence.

Every crisis perhaps presents an opportunity. In Europe, we're facing an influx of 2 million refugees, mostly from Syria, which poses interesting possibilities. Refugees could reenergize sections of the cities. They offer to architecture an interesting provocation or invitation to do good work and collaborate in interesting ways.

\section{-Rem Koolhaas interview at FastCoDesign ${ }^{13}$}

Even though it is hard to shape a clear answer as to what are our best practices as architects within this very complex landscape, we feel that the current 'from the top', paternalistic structures of relief response offer typical, unidirectional philanthropy and as a response we could actively engage with the above mentioned bottom up initiatives. We can employ simple tools that materialize the politics of transiency in alternative ways. Decriminalization of squatting, rent control, diverting funding from detention centres and military equipment, and rehabilitating housing affordability for everyone are a few of these tools.

It is also important to identify systems for rethinking disciplinary boundaries and establish forums of scientific, historical, cultural studies and creative works that embody ephemerality and nuance. This interdisciplinary inquiry inspires the book publication titled Transient Spaces as mentioned in the beginning of this paper. The publication is established as a project of interaction, as a forum for faculty, students, scholars and practitioners to explore the concept of impermanence in its various social and formal manifestations. ${ }^{14}$

\section{ENDNOTES}

1. UNHCR, "Global Trends, Forced Displacement in 2016 Report," UNHCR official website, accessed June 29, 2018, http://www.unhcr.org/globaltrends2016.

2. UNCHR, "Global Trends, Figures at Glance," UNHCR official website, accessed June 29, 2018, http://www.unhcr.org/en-us/figures-at-a-glance.html.

3. UNHCR, "Who is a Refugee," UNHCR official website, accessed June 29, 2018, https://www.unrefugees.org/refugee-facts/what-is-a-refugee/.

4. Daniel Howden and Apostolis Fotiadis, "Where Did the Money Go? How Greece Fumbled the Refugee Crisis," The Guardian,
March 9, 2017, https://www.theguardian.com/world/2017/mar/09/ how-greece-fumbled-refugee-crisis.

5. Jacques Rancière, "Who Is the Subject of the Rights of Man?," The South Atlantic Quarterly 103, no. 2 (2004): 297-310.

6. The essay is included in the expected publication Transient Spaces (2019). Platon Issaias and Theodossis Issaias, "Displaced, In Place and In Transit, Refugee Population in Greece and the Formation of Planning Protocols and Domestic Machines" in Transient Spaces, eds., Loukia Tsafoulia and Suzan Wines (New York: The City College of New York, expected 2018), 44.
7. More information on the size, capacity and shelter types for each one of the case study sites: Elaiwnas Refugee Camp, Athens (Center). Open Space/ Former Industrial Area. Data (2017): 96 Prefab Shelters hosting 750 people (8-10 people per prefab). 32,000 m2 land (appr. 350,000sq.feet) Prosfygika Alexandras, Athens (Center). Between 1933-1935 the Alexandras Building Complex was built to house the 1922-1923 Asia Minor disaster refugees. Data: 228 apartments along 8 Bauhaus style buildings. $4,500 \mathrm{~m} 2$ build and $10,000 \mathrm{~m} 2$ landscape area. Both sites are located in central neighborhoods of Athens, therefore issues or segregation and connectivity with the urban fabric are studied. Skaramagkas Refugee Camp, Athens. Former Shipyard Facility. Data (2017): 407 Prefab Shelters hosting 3200 people (6-10 people per prefab). 87,000 m2 land (appr. 400,000sq.feet). Schisto Refugee Camp, Athens. Former Military Camp. Data (2017): 149 Prefab Shelters hosting 820 people (4-6 people per prefab). 37,000m2 land (appr. 400,000sq.feet). Both of the sites: (a) Are in close proximity therefore issues of urban connectivity and expansion are studied. (b) Have interesting landscape qualities and proxinity to the waterfont rective therefore a focus on re-use. Have a challenging relationship to the urban grid respectively.

8. Actors present at camps: Reception and Identification Service, Hellenic Police, Ministry of Education, various INGOs/ Ministry of Health. The camp sites from 2015 to last year were managed and secured by the Hellenic police and the Greek Army. Cooked food was distributed to refugees first via ment of cleaning and WASH units are organized run by the airforce. Camp residents have access to the labour market, to the national education system and to the national Health Care System. There has been much discussion in humanitarian studies about the appropriateness (or not) of using an area-based approach which could provide such overlapping benefits to populations, regardless of their legal status. See for example: D. Sanderson, "Implementing Area-Based Approaches (ABAs) in Urban Post-Disaster

9. Rebeliskos, "The Refugees in Alexandria Still Remember their History," blog post on Dimension of Information website, March 19, 2014, https://diastasienimerosis.wordpress.com/2014/03/19/

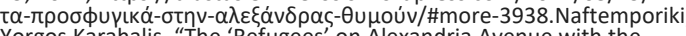
Yorgos Karahalis, "The 'Refugees' on Alexandria Avenue with the Reuters Lens," photo essay on the Naftemporiki.gr official website, February 5, 2014, https://www.naftemporiki.gr/slideshows/761841/ ta-prosfugika-tis-leoforou-aleksandras-me-to-fako-tou-reuters/all.

10. Winning competitions for the Studio's Schisto Team work: "Ristainability Awards 2017, Urban Design, Rethinking the Future official website, accessed July 24, 2018, https:// www.re-thinkingthefuture.com/rtfsa2017-urban-design/

11. "Results of the Competition Cities of Tomorrow," Project Earth 2, accessed July 24, 2018, https://www.projectearth2.org/10096. For the overall design studio work refer to the link with the studio's research book: https://drive. google.com/file/d/OB9PFDGtWM4vQMnhORTRRbWc2Y3M/view.

12. Saskia Sassen, Expulsions: Brutality and Complexity in the Global Economy (Cambridge, MA: Belknap Press, 2014), 7

13. Diana Budds, "Rem Koolhaas: 'Architecture Has A Serious Problem Today,' Fast Company, May 21, 2016, https:// www.fastcodesign.com/3060135/innovation-by-design/
rem-koolhaas-architecture-has-a-serious-problem-today.

14. The book publication is organized in collaboration with Suzan Wines, faculty of City College with the help from the Transient Spaces studio students and the support of the Department Chair, Julio Salcedo. It is expected to conclude by the end of 2018. Follow the initiative's website for updates: https://transientspaces tumblr.com/land. 